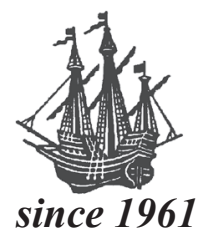

Baltica

BALTICA Volume 34 Number 2 December 2021: 148-156

https://doi.org/10.5200/baltica.2021.2.2

\title{
Modelling of underwater noise emissions by ships in Klaipėda Strait, Lithuania
}

\author{
Donatas Bagočius*, Aleksas Narščius, Olga Anne
}

Bagočius, D., Narščius, A., Anne, O. 2021. Modelling of underwater noise emissions by ships in Klaipedda Strait, Lithuania. Baltica, 34 (2), 148-156. Vilnius. ISSN 1648-858X.

Manuscript submitted 8 April 2021 / Accepted 16 October 2021 / Available online 09 November 2021

(C) Baltica 2021

\begin{abstract}
One of the United Nations Sustainable Development Goals regarding "conservation and sustainable use of the oceans, seas, and marine resources" emphasizes the urgency of eliminating harmful effects on the sea and its biota, where the role of anthropogenic activities is crucial. The global trend of merchant shipping is increasing, thus enlarging underwater noise levels. As a result, greater noise can harm aquatic animals in their habitats. In the Baltic Sea, the underwater sound pressure levels are now being evaluated utilizing noise measurement, modelling, and mapping. In areas such as narrow ship passages, namely lagoons, channels, or straits, the ambient underwater noise modelling becomes very complex, even though these EU inland waters are regarded by legislation as part of the marine basin. For instance, the Klaipeda Channel (Klaipeda Strait), connecting the Baltic Sea and the Curonian Lagoon, is regarded by the national Lithuanian legislation as part of marine waters, where the environmental status should be evaluated according to the EU Maritime Strategy Framework Directive. In this narrow channel, an alternative to the modelling of ambient sound pressure levels can be applied to understand the long-term trends of vessel-sourced noise emissions. In this paper, an example of application of ship noise emission modelling for a narrow Klaipeda Harbour area is presented, along with the results obtained throughout 2015-2017. The modelled noise levels in the harbour area reached the median levels of $112.5 \mathrm{~dB}$ in 2015 and $102.6 \mathrm{~dB}$ re $1 \mu \mathrm{Pa}^{2}$ in 2017 . The maximum emitted instantaneous sound pressure levels by ships reached $173.7 \mathrm{~dB}$ in 2015 and $179.4 \mathrm{~dB}$ re $1 \mu \mathrm{Pa}^{2}$ in 2017 in the area of interest.
\end{abstract}

Keywords: Baltic Sea; harbour area; ships source levels; noise predictions

Donatas Bagočius* (donatas.bagocius@jmtc.ku.lt), Klaipéda University, H. Manto str.84, Klaipéda, Lithuania; Aleksas Narščius (aleksas@apc.ku.lt), Klaipèda University, H. Manto str. 84, Klaipéda, Lithuania, Klaipéda University of Applied Sciences, Jaunystès str. 1, Klaipèda, Lithuania; Olga Anne (olga.anne@ku.lt) Klaipéda University, H. Manto str. 84, Klaipéda, Lithuania

*Corresponding author

\section{INTRODUCTION}

Human activities, such as commercial shipping, military activities, or scientific exploration of the seabed inevitably introduce a certain amount of noise energy into marine ecosystems. Its impact can harm marine mammals (MMC 2007), sea birds (Crowell 2016), and fish (Slabbekoorn et al. 2010).

Likewise, the future safety of the Earth's hydrosphere is strongly supported by the UN Sustainable Development Goals, especially SDG 14 that is directly related to the health and productivity of the seas
(Armstrong 2020). As the global shipping is trending up, the number and size of commercial vessels in the merchant fleet have increased significantly during the past 50 years (Hildebrand 2009). It is expected that maritime transportation in European Union (EU) countries will grow in the future. The contributions from Extra- and Intra-European trades are expected to contribute substantially to maritime transportation. This will result in a modal shift of transport from road to the sea and increase in vessel size to enable more efficient and cost-saving freight transport throughout the EU (Balticlines 2016). 
The environmental indicators designed for evaluating marine ecosystems in European Union are targeted to secure conservation of the EU seas. The EU Marine Strategy Framework Directive requirements regarding underwater noise control and indicators of good environmental status (Tasker et al. 2010) enforce EU member states to evaluate the levels of underwater noise energy introduced into the marine environment. In the Baltic Sea basin, underwater noise levels are beginning to be evaluated using noise measurement, modelling, and mapping (ICES 2020). Within the regional Baltic Sea project "BIAS", recent measurements of ambient noise revealed the correlation of sound pressure levels with the shipping traffic density. For example, the $5^{\text {th }}$ percentile ambient noise levels at Fehmarnt Belt, Germany, exceeded the $150 \mathrm{~dB}$ reference to $1 \mu \mathrm{Pa}^{2}$ level (the difference in atmospheric decibel scale $\mathrm{dBA}$ and the underwater decibel scale $\mathrm{dB}$ re $1 \mu \mathrm{Pa}^{2}$ roughly equals $61.5 \mathrm{~dB}$, see Finfer et al. 2008) where the measurement stations were located in the most intense shipping traffic area of the Baltic Sea (Mustonen et al. 2019). Despite these findings, some inland waters of the Baltic Sea, such as narrow ship passages, i.e. lagoons, channels, or straits are regarded by EU regulations as part of the marine basin where underwater noise levels should be reported.

Every individual ship produces its unique acoustic signature often radiating sharp tonals that depend on its speed, load, and other factors. Large vessels produce three main types of underwater noise originating from the machinery through their hull, cavitating propeller, and hydrodynamic interaction (Hildebrand 2009). These unwanted underwater sound types form a measured vessel sound spectrum that consists of two parts: 1) the broadband continuous spectrum (noise levels are a continuous function of frequency) and 2) the discontinuous spectrum of tonal noise. The idealized spectrum is described by the continuous spectrum having the negative slope of $6 \mathrm{~dB}$ per octave above $200 \mathrm{~Hz}$ and the spectrum having a no-slope below $200 \mathrm{~Hz}$ (Urick 1983). At low ship speeds, the ship's radiated noise spectrum is mainly dominated by the noise of diesel generators, and at high speeds, the propulsion-related sources, firing rate harmonics, and helix blade rate harmonics dominate in the ship's noise spectrum (Arveson, Venditis 2000). Historicalscientific data indicate that as ship speed increases, a certain speed limit is reached where ship propeller cavitation begins and radiated ship noise dramatically increases. The propeller cavitation-radiated noise forms a noise spectrum involving a peak within frequency bands of 100-1000 Hz. As ship speed increases, this peak shifts to lower frequencies - this process is attributable to the formation of larger bubbles, which is a consequence of a greater ship propel- ler rotation speed. Modern hull cargo and tanker ships are known to cavitate at a speed approaching 9 knots (Jalkanen et al. 2018), although historical data indicate that the cavitation of comparatively small vessels can start at a speed between 3-5 knots (Urick 1983).

Ship noise source models have been developed since the Second World War, although not all of them are available (Jalkanen et al. 2018). Historically, most popular ship source models have been proposed by Donald Ross. Further developments of Ross models were proposed - they include RANDI models. A different approach based on a statistical analysis of noise measurements for a large number of merchant ships in transit has been proposed by Whales and Heitmeyer (Liefvendahl et al. 2015).

Despite the development of ambient noise models that provide a realistic simulation of a total noise field obtained by calculating wind and shipping noise (Etter 2012), there are confined environments, i.e. narrow channels such as Klaipeda Strait where sound propagation modelling becomes extremely complex. This particular area is known to have elevated underwater ambient noise levels that are caused by introduction of shipping sound energy into the underwater environment (Bagočius 2013). Due to local regulations, this area is regarded as a marine area where environmental status should be evaluated even if the ambient noise modelling becomes inefficient and time-consuming. As an alternative, ship source models like "Ship Traffic Emission Assessment Model" can be effectively applied to assess underwater sound emissions and to report the change of noise levels in long-term trends. The aim of this paper is to present an application of such a model for a confined channel.

\section{MATERIALS AND METHODS}

\section{Description of the research area}

The Klaipeda Harbour is a very shallow water body, with a depth of approximately $14 \mathrm{~m}$ at its centre. The west side of the harbour area has the shoaling depths, starting at 50-100 m distance from the shore. Here, some areas exceed the depth of $14 \mathrm{~m}$. The harbour channel prolongs for $\sim 11 \mathrm{~km}$ and at its central part has an approximate width of 500 meters and is surrounded by concrete berths, near which the depth is $\sim 14 \mathrm{~m}$ (based on GIS analysis of bathymetry scanned by Coastal Research and Planning Institute 2013). The Klaipeda Harbour area is shown in Fig. 1.

In a very narrow area surrounded by berths, such as Klaipeda Harbour is, the description of propagating sound waves ant its multiple reflections from the berths becomes a very complex task. Moreover, the sound propagation in this area is affected by the cutoff frequency phenomenon. Therefore, the cut-off 


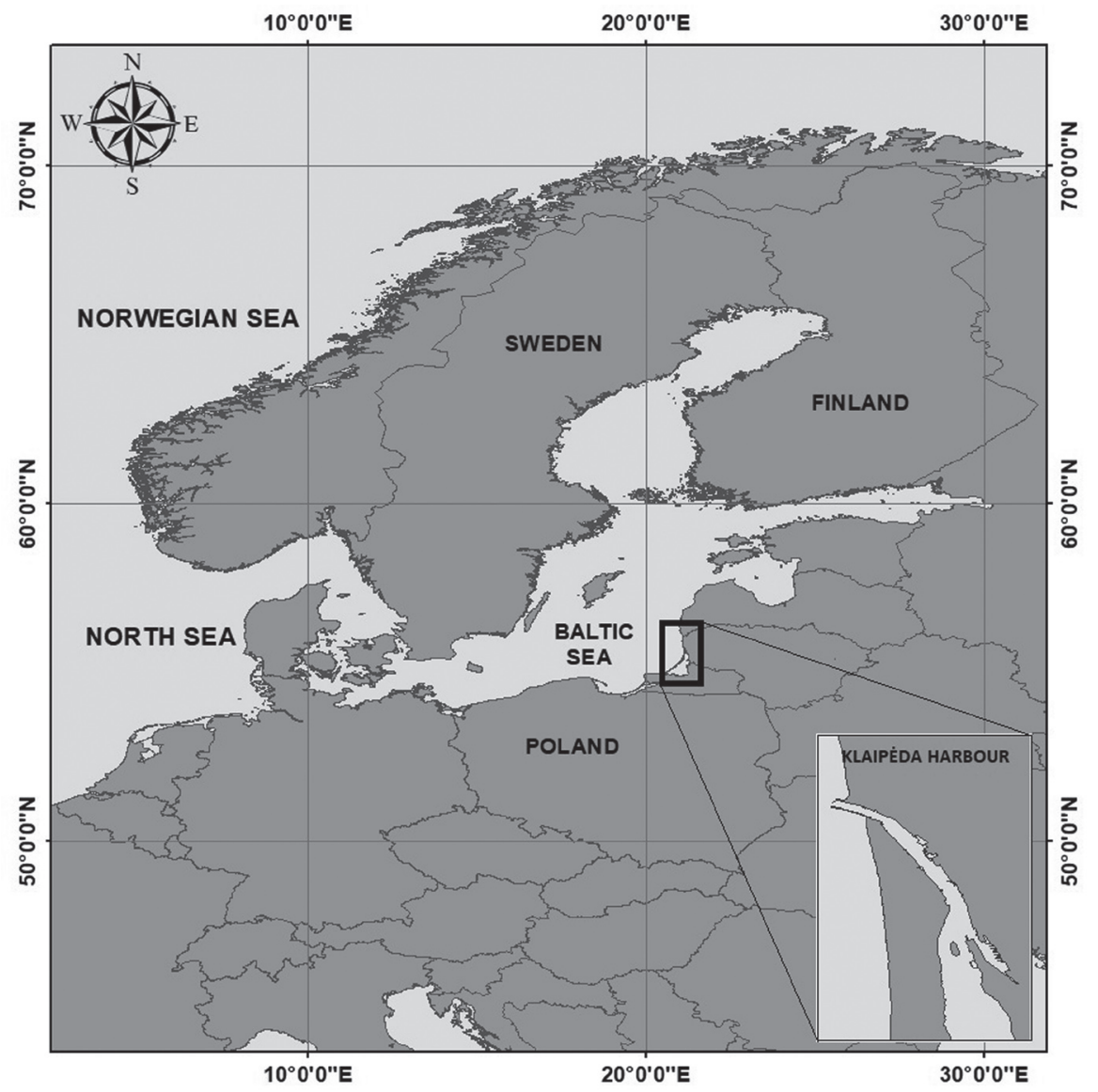

Fig 1 The research area: Klaipeda Harbour

frequencies for particular depths were determined using the following equation (Urick 1979, as cited in Au, Hastings 2008):

$$
f_{c u t}=\frac{C w / 4 H}{\sqrt{1-C w^{2} / C s^{2}}}
$$

where $f_{\text {cut }}$ is the cut-off frequency bellow which sound cannot propagate $(\mathrm{Hz}), C_{w}$ is the sound speed in water $(\mathrm{m} / \mathrm{s}), C_{s}$ is the sound speed in bottom sediments $(\mathrm{m} / \mathrm{s})$, and $H$ is the water depth $(\mathrm{m})$. The empirical sound speed values were used: $C_{w}=1500 \mathrm{~m} / \mathrm{s}$ and $C_{s}=1650 \mathrm{~m} / \mathrm{s}$ for sandy bottom (Jensen et al. 2011), where the Klaipeda Harbour bottom is covered by sandy substrate (Trimonis et al. 2003). Two $1 / 3$ octave bands $-63 \mathrm{~Hz}$ and $125 \mathrm{~Hz}$ - are the bands representing shipping noise in EU standards (Dekeling et al. 2013). At low ship speeds, all spectral frequency bands are dominated by the machinery noise. At higher speeds, a prominent range is formed at $50-100 \mathrm{~Hz}$ frequency bands. Typically, 63-Hz peak levels represent a narrow-band propeller blade harmonics, and in the $125-\mathrm{Hz}$ band, separate blade tonals are less discernible showing a mixture of machinery and helix noise (see Arveson, Venditis 2010). Therefore, the depth of the cut-off frequency (Eq. 1) for the $63-\mathrm{Hz}$ band was defined to be $14.3 \mathrm{~m}$, and the depth of the cut-off frequency for $125 \mathrm{~Hz}$ was $7.2 \mathrm{~m}$. Due to the acquired values of cut-off frequencies for Klaipeda Harbour area, the $63-\mathrm{Hz} 1 / 3$ octave band was rejected in this research during the analysis, considering that sound waves in this particular frequency band will be greatly attenuated. Still, it is notable that in shallow water environments, the sound waves bellow cutoff frequencies at some extent can employ different sound propagation mechanisms and can be conducted through the bottom medium (Urick 1984).

\section{Modelling of transient ship underwater noise levels}

Underwater noise emitted by ship sources was estimated using a ship source model developed by Breeding et al. (1996). The script in MATLAB ${ }^{\circledR}$ application was written to model underwater ship noise emissions. A computed noise source spectrum is given in the equation below (presented as in Liefvendahl et al. 2015):

$$
S(f)=S_{0}(f)+S^{\prime}(V, L)+S^{\prime \prime}(f, L),
$$

where $S_{0}$ is the base spectrum and $S^{\prime}$ is scaling based on ship parameters ( $V$ is ship speed in knots and $L$ is ship length in feet). The third term, $S^{\prime \prime}$, is a correction term for low frequencies (approximately below $200 \mathrm{~Hz}$ ). The base spectrum is equal to 
$S_{0}(f)= \begin{cases}-10 \log _{10}\left(10^{F_{1}(f)}+10^{F_{2}(f)}\right) & \text { for } f<500 \mathrm{~Hz} \\ F_{3}(f) & \text { for } f>500 \mathrm{~Hz}\end{cases}$

$F_{i}=a_{i}+B_{i} \log _{10} f$, the coefficients are presented in Table 1.

Table 1 Model base spectrum coefficient values

\begin{tabular}{|c|c|c|}
\hline$i$ & $a_{i}$ & $b_{i}$ \\
\hline 1 & -14.340 & -1.06 \\
\hline 2 & -21.425 & 3.32 \\
\hline 3 & 173.20 & -18.0 \\
\hline
\end{tabular}

The spectrum scaling function due to vessel parameters is equal to

$$
S(V, L)=60 \log _{10}\left(\frac{V}{V_{\text {ref }}}\right)+20 \log _{10}\left(\frac{L}{L_{\text {ref }}}\right)+3
$$

The ship source levels are computed by defining an average as one with the reference speed $V_{\text {ref }}$ of 12 knots $(22.2 \mathrm{~km} / \mathrm{h})$ and the reference ship length $L_{r e f}$ of 300 feet $(91.4 \mathrm{~m})$. This average ship is assigned a source level $S(V, L)$ as a function of frequency. The noise source levels of the vessels are then computed on the basis of their individual speeds and lengths by the empirical equation (2) (Ross 1987).

The third component of the model (low-frequency correction) is given by the equation below:

$$
S^{\prime \prime}(f, L)=r(f) \frac{L^{1.15}}{3643},
$$

where $r$ is a continuous low-frequency weighting function given by the following equation:

$$
r(f)=\left\{\begin{array}{lr}
8.1, & f<f_{c 1} \\
22.3-9.77 \log _{10}(f), & f_{c 1}<f<f_{c 2} \\
0, & f \geq f_{c 2}
\end{array}\right.
$$

The frequency limits are within the bounds of $f_{c l}=$ $28.4 \mathrm{~Hz}$ and $f_{c 2}=191.6 \mathrm{~Hz}$.

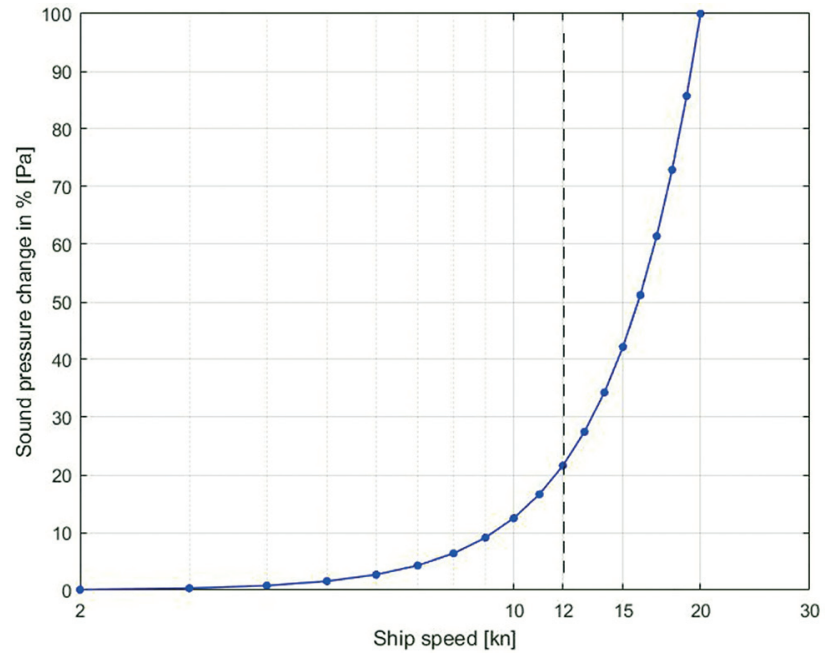

Fig 2 The emitted ship sound pressure increases due to increasing vessel speed (vessel LOA $110 \mathrm{~m}$ ). The dashed line indicates the cavitation inception speed region
The spectral noise model was tested with merchant vessel parameters: length overall (LOA) $110 \mathrm{~m}$ (median of the LOA of all vessels registered at LTU marine area in 2017) and vessel speeds from 2-20 knots $(3.7-37 \mathrm{~km} / \mathrm{h})$ with $1-\mathrm{knot}$ steps.

The test result is presented in Fig. 2. The area (region) of the cavitation inception speed of the ship (vertical dashed line) at 12 knots $(22.2 \mathrm{~km} / \mathrm{h})$ can be observed. In the speed region from 2-12 knots, the sound pressure in Pascal increases to nearly $20 \%$, and for the 12-20 knot range the sound pressure in Pascal increases from $\sim 20 \%$ to $100 \%$, clearly indicating the increase of cavitation-related noise in modelled results.

\section{Determination of sound pressure levels in the $1 / 3$ octave band}

The acquired sound pressure levels were filtered using $1 / 3$ octave filters (Betke et al. 2015). The $1 / 3$ octave centre, lower, and upper cut-off band frequency limits were defined as standard (IEC/ANSI limits).

Centre frequency:

$$
f_{m}(x)=f_{r}(G)^{(x-30) / 3},
$$

where $f_{m}$ is centre frequency, $f_{r}$ is reference frequency $(1000 \mathrm{~Hz}), X$ is IEC/ISO band number, and $G$ is octave ratio (base 10 exact) $10^{3 / 10}$.

Lower cut-off frequency:

$$
f_{\text {low }}(x)=f_{m}(x) G^{-1 / 6},
$$

where $f_{\text {low }}$ is lower cut-off frequency.

Upper cut-off frequency:

$$
f_{\text {high }}(x)=f_{m}(x) G^{1 / 6},
$$

where $f_{\text {high }}$ is upper cut-off frequency.

The information on the $125-\mathrm{Hz} 1 / 3$ octave band's cut-off and centre frequency filters applied is given in Table 2.

Table 2 Octave band cut-off and centre frequencies (Betke et al. 2015)

\begin{tabular}{|c|c|c|}
\hline No & \multicolumn{2}{|c|}{ Parameter } \\
\hline 1 & IEC/ANSI band & $21^{\text {st }}$ \\
\hline 2 & Band name & $125.0 \mathrm{~Hz}$ \\
\hline 3 & $f_{\text {low }}$ & $112.2 \mathrm{~Hz}$ \\
\hline 4 & $f_{m}$ & $125.9 \mathrm{~Hz}$ \\
\hline 5 & $f_{\text {high }}$ & $141.3 \mathrm{~Hz}$ \\
\hline 6 & $1 \mathrm{~Hz}$ bins & 29 \\
\hline
\end{tabular}

The $1 / 3$ octave sound pressure levels were acquired integrating the modelled power spectrum levels and using the equation (Madsen et al. 2006).

$$
S P L_{125 \mathrm{~Hz}}=N_{0}(f)+10 \log _{10}(B W),
$$

where $S P L$ is sound pressure level (unit's $\mathrm{dB}$ re $\left.1 \mu \mathrm{Pa}^{2}\right), N_{0}(f)$ is noise spectrum level in the $125-\mathrm{Hz}$ 
frequency band obtained using Eqs. $2-5$, and $B W$ is bandwidth of the $1 / 3$ octave band (Table 2).

\section{Ships data and sound mapping}

To define yearly and monthly sound pressure levels, the analysis of ship automatic identification system (AIS) data, provided by the Lithuanian Transport Safety Administration, was carried out aiming at the 2015 and 2017 period. In the research area, the AIS data consisted of 431,856 lines in 2015 and 444,516 lines in 2017 and had 4-minute intervals (later filtered to 16-min intervals to reduce the volume of data for processing). The analyzed AIS data were bounded by the rectangular Klaipeda Harbour area within coordinates N 55.730314; E 21.07698 and N 55.643178; E 21.16516 (WGS), covering an area of $54 \mathrm{~km}^{2}$. The data related to the Klaipeda Harbour statistics were acquired from the Klaipeda Sea State Port Authority (KSSP 2020).

The sound pressure level data grids were postprocessed using ArcGIS ${ }^{\circledR}$ software. Aerial vector layers were created to map ship noise emission estimates in the $125-\mathrm{Hz} 1 / 3$ octave band (energy summation by Eq. (10) was used). The noise data were processed in $100 \times 100 \mathrm{~m}$ data cells, assuming that sound pressure levels are the product of the sum of sound pressure levels at the time $t$ (see Jalkanen et al. 2018):

$$
S P L_{125 \mathrm{~Hz}}\left[\mathrm{~dB} \text { re. } 1 \mathrm{~m}, .1 \mu \mathrm{Pa}^{2}\right]=10 \log _{10} \frac{P_{125 \mathrm{~Hz}}^{\mathrm{tot}}}{P^{2} \text { ref }} .
$$

The total source sound pressure levels, which can be converted into units of radiated power $\mathrm{J} \mathrm{s}^{-1}$ for reporting purposes, in each data cell are given by

$$
P_{125 \mathrm{~Hz}}^{2^{\text {tot }}}=\sum_{1}^{N} P_{125 \mathrm{~Hz}, n}^{2}(t) .
$$

The total source sound pressure levels modelled in each cell represent the total noise levels in each $100 \times 100 \mathrm{~m}$ cell, assuming the average size of the ships cruising at Klaipeda Harbour is greater than $100 \mathrm{~m}$ (in 2017, the average vessel size LOA registered by AIS receivers in the area was $123 \mathrm{~m}$ ). The source levels represent the emitted noise intensities of transient sound sources (ships), ignoring propagation and attenuation phenomena in the narrow channel due to possible sound propagation loss modelling errors. These would arise with the description of the propagating sound wave reflections from the channel berths, due to the channel being only a few 100 s of meters wide at a considerable part of the harbour. The empirical model "Research Ambient Noise Directionality 3.1" (RANDI 3.1) that was applied to compute the total source sound pressure levels in the high resolution grid cells is a good representative of ship source levels at low frequency bands. For instance, Jiang et al. (2020) in their study defined the RANDI
3.1 model results as having the absolute median error bellow $3 \mathrm{~dB}$ in the $125-\mathrm{Hz}$ band, in comparison to the measured sound pressure levels of the ship sources. Still, the absolute error can be slightly greater in higher and lower frequency bands. It should also be noted that studies of the comparison of available empirical ship source models reveal an impact of experimental methodology on the modelling results, using these models where the factors, such as the closest point of approach (CPA), compensation of the surface image effects (Lloyd mirror effects), hydrophone directionality angle, and estimation of ships source depths, may affect measurement results which were used to fit empirical models (Chion et al. 2019).

The sound pressure levels can be geographically visualized using interpolation methods (see Hatch et al. 2008). To represent the spatial extent of the sound pressure levels in the Klaipeda Harbour area, the data were interpolated using ArcGis Geostatistical Analyst ${ }^{\circledR}$. The diffusion interpolation method was used, which produces predictions on automatically selected grids (cells), where the distance between the neighbouring cell centres is a Euclidean one. For interpolation, the bandwidth of the diffusion kernel was equal to 0.00073 and 100 iterations were used.

\section{RESULTS}

Using the above-described methodology, underwater noise emissions were assessed and a noise map was created. The annual ship noise emissions in the Klaipeda Harbour area reached median levels of $112.52 \mathrm{~dB}$ re $1 \mu \mathrm{Pa}^{2}$ in 2015 and $102.60 \mathrm{~dB}$ re $1 \mu \mathrm{Pa}^{2}$ in 2017 (difference was equal to $9.9 \mathrm{~dB}$ ). The maximum emitted sound pressure level reached $173.74 \mathrm{~dB}$ re $1 \mu \mathrm{Pa}^{2}$ in 2015 and $179.43 \mathrm{~dB}$ re $1 \mu \mathrm{Pa}^{2}$ in 2017 in the area of interest. Yearly sound pressure levels dropped in 2017 in comparison to 2015. The normalized functions of the probability density distribution of emitted sound pressure levels are depicted in Fig. 3.

Monthly median levels reached their maximum values: $129.25 \mathrm{~dB}$ re $1 \mu \mathrm{Pa}^{2}$ SPL in February 2015 and $123.03 \mathrm{~dB}$ re $1 \mu \mathrm{Pa}^{2}$ SPL in May 2017. Minimum levels were observed in December of 2015 and 2017, reaching $73.62 \mathrm{~dB}$ re $1 \mu \mathrm{Pa}^{2}$ and $69.44 \mathrm{~dB}$ re $1 \mu \mathrm{Pa}^{2}$ SPL, respectively. Monthly statistics are depicted in Fig. 4 as violin plots.

The acquired monthly median levels reflect shipping traffic seasonality. Monthly sound pressure levels tend to decrease at the end of the year in contrast to other seasons. The acquired data is summarized in Table 3.

It is noteworthy that a decrease in sound pressure levels throughout 2015-2017 has an absolute negative correlation (correlation coefficient was equal to $1.0^{-1}$ ) with the cargo loads. 


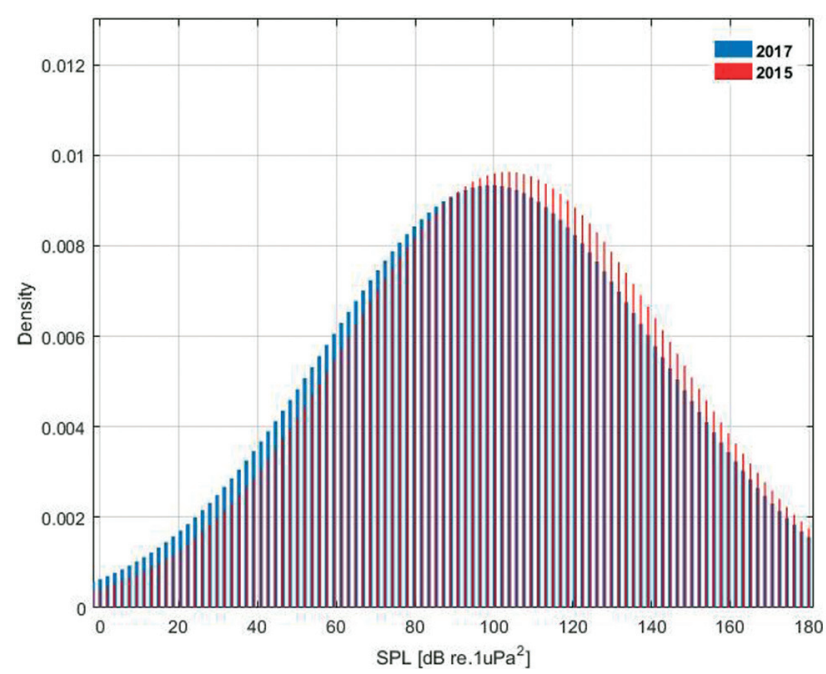

Fig. 3 Normalized probability density distributions (normal distribution fit) of emitted sound pressure levels (125-Hz 1/3 octave band) in the Klaipeda Harbour area throughout 2015-2017

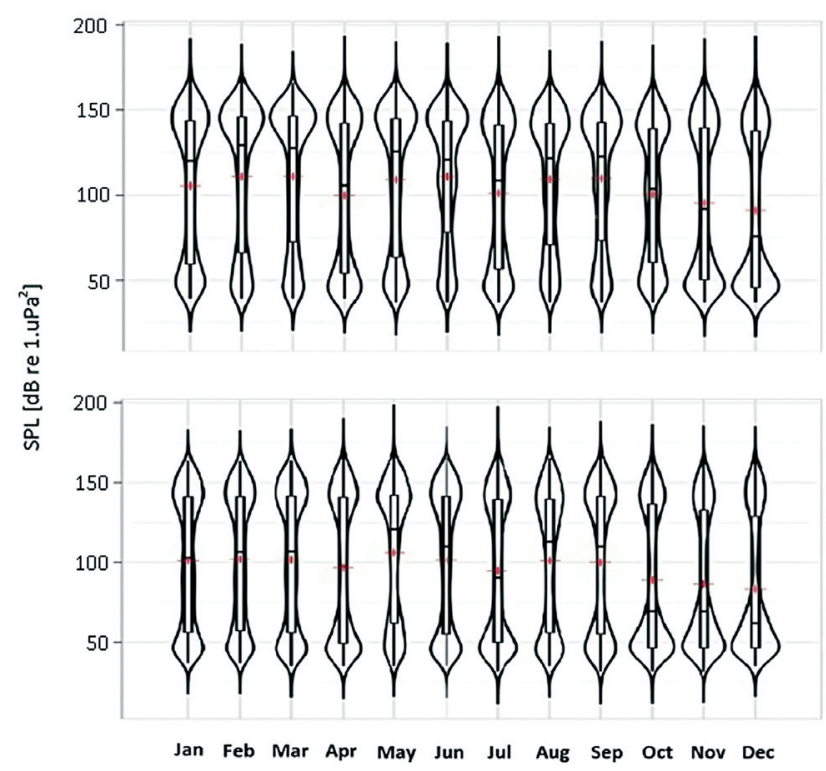

Fig. 4 The violin plots of monthly sound pressure levels: upper panel - 2015, lower panel - 2017. The red line indicates average levels, the centre mark of the box plot indicates median levels, whereas the bottom and top box edges indicate $25^{\text {th }}$ and $75^{\text {th }}$ percentiles, respectively. The whiskers extend to extreme data points. Vertical probability density represents bimodal functions

Table 3 Sound pressure levels (yearly statistics) in the 125 $\mathrm{Hz} 1 / 3$ octave band at the Klaipeda Harbour

\begin{tabular}{|c|c|c|}
\hline $\begin{array}{c}\text { Parameter/ } \\
\text { Period }\end{array}$ & 2015 & 2017 \\
\hline $90 \%$ & $152.034 \mathrm{~dB}$ re $1 \mu \mathrm{Pa}^{2}$ & $152.529{\mathrm{~dB} \mathrm{re} 1 \mu \mathrm{Pa}^{2}}^{2}$ \\
\hline Median & $112.517 \mathrm{~dB}$ re $1 \mu \mathrm{Pa}^{2}$ & $102.596 \mathrm{~dB}$ re $1 \mu \mathrm{Pa}^{2}$ \\
\hline $10 \%$ & $45.451 \mathrm{~dB}$ re $1 \mu \mathrm{Pa}^{2}$ & $45.458 \mathrm{~dB}$ re $1 \mu \mathrm{Pa}^{2}$ \\
\hline Local ships & 2666 calls & 2280 calls \\
\hline Guest ships & 4393 calls & 4291 calls \\
\hline Total ships & 7059 calls & 6571 calls \\
\hline Loaded cargoes & 38.51 million tons & 43.17 million tons \\
\hline
\end{tabular}

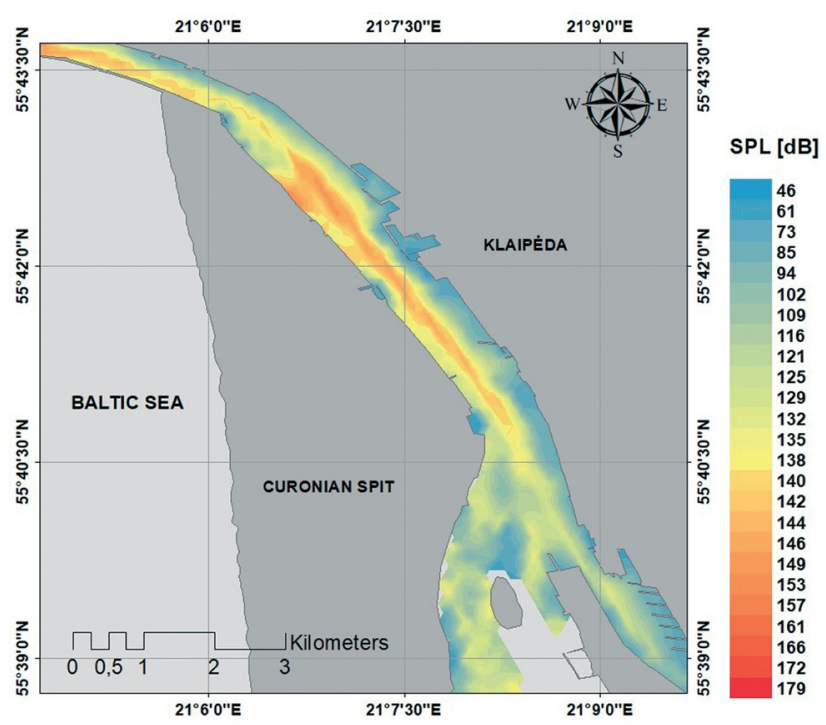

Fig. 5 Ship noise emissions map for the Klaipeda Harbour area for $2017(125-\mathrm{Hz}$ 1/3 octave band $\left(\mathrm{dB}\right.$ re $\left.\left.1 \mu \mathrm{Pa}^{2}\right)\right)$

The spatial distribution of sound pressure levels in the $125-\mathrm{Hz} 1 / 3$ octave band in the harbour area was modelled. A geographical map representing the spatial extent of ship noise emissions in the area of interest in 2017 (emitted total pressure) is depicted in Fig. 5.

The spatial distribution of sound pressure emitted by ships can be observed as concentrated at the central part of the Klaipeda Channel, where noise levels exceed $170 \mathrm{~dB}$ re $1 \mu \mathrm{Pa}^{2}$. It is worth noting that the applied model allows to post-process sound pressure levels in $100 \times 100 \mathrm{~m}$ size cells, where data statistics can be treated in any separate data cell.

\section{DISCUSSION}

In this research, spectral source levels were acquired utilizing a spectral source model developed by Breeding et al. (1996). Still, other analogue source spectral models, i.e. SONIC, as well as a model by Wittekind (2014) or others, might be utilized (see also Chion et al. 2019). However, some ship source models require special data input (Liefvendahl et al. 2015). In the frequency band of interest, the spectral model is in good agreement with ship noise measurement results in shallow water areas (Jiang et al.2020).

The modelled underwater noise levels emitted by ships reached their peak in the central part of the Klaipeda Harbour area. Monthly data analysis revealed the seasonality of noise levels: median sound pressure reached its maximum from February through September 2015 and from May through September 2017, while the levels decreased in December. This seasonality can be explained by trends inherent to merchant shipping in the research area. Another interesting feature is the drop in the median yearly noise 
level throughout 2015-2017 - it reached $9.9 \mathrm{~dB}$, most likely corresponding to the drop in the number of ship calls. In contrast, the tonnage of loaded cargoes in the Klaipeda Harbuor increased during the aforementioned period. These results are consistent with the assumption that the passage of larger vessels, instead of smaller ones, in a particular area can lead to the reduction of cumulative noise levels. The instantaneous noise emission by larger vessels is greater, but their carrying capacities reduce the number of cruising vessels (Merchant 2019). It is notable that the maximum instantly emitted sound pressure levels reached $173.74 \mathrm{~dB}$ re $1 \mu \mathrm{Pa}^{2}$ in 2015 and $179.43 \mathrm{~dB}$ re $1 \mu \mathrm{Pa}^{2}$ in 2017. It is also worth emphasizing that in the research area, vessel speed is limited to 8 knots (low steaming) due to navigation safety reasons (KSSP 2020). The acquired violin plots (Fig. 4) revealed the bimodality of all monthly data density functions, showing the accumulation of noise levels in two regions of density functions - lower emitted noise levels of vessels while these berth and higher emitted noise levels of vessels while these cruise at a regular speed in the harbour. As found by Wittekind (2014), ships of different types will cavitate at speeds above 8 knots. Theoretical cavitation inception speed research indicates that most ships will cavitate at a speed of 14 knots, although most cargo-carrying vessels and tankers start to cavitate at inception speeds close to 9 knots (Jalkanen et al. 2018), whereas smaller ships might start to cavitate at speeds as low as $3-5$ knots (Urick 1983). The obtained results (Fig. 3) show negative skewness of the probability density functions in 2015 and 2017 . The processed data of ship noise emissions with the result of negative skewness in particular reveal the accumulation of noise levels towards higher sound pressure levels, thus showing the tendency for vessels speeds to be close to their allowable maximum.

The annual noise maps were drawn for the narrow Klaipeda Strait, and vector layers in $100 \times 100 \mathrm{~m}$ data cells were created. The spatial analysis of the data reveals that ship noise levels usually accumulate at the central part of the Klaipeda Strait (Fig. 5). Additionally, our technique allows a statistical analysis of the data in each cell as a supplement. Furthermore, underwater noise emissions can be analyzed and routine annual summary reporting can be carried out (see Jalkanen et al. 2018) in 1/3 octave bands, as is described in MSFD.

The underwater noise emitted by cruising vessels at Klaipeda Harbour can affect the fish that are sensitive to sound pressure. Passing ships may alter the behaviour of these aquatic animals, induce their avoidance reactions, as well as alter swimming direction and schooling behaviour. As found by some research, fish species can suffer from temporary hearing threshold shifts and recoverable loss of sensory cells (Popper et al. 2014). The Klaipeda Harbour area is a spawning migration lane for pressure-sensitive fish species, e.g. twaite shad (Allosa falax) (Maksimov et al. 2007) that can be affected negatively by underwater sound.

It has been shown that ship speed restrictions can reduce their noise levels. However, as slower vessels take longer to transit, the trade-offs emerge between the duration and the emitted noise levels. Some research indicates that optimal trade-off between duration and intensity of noise radiation can be achieved at vessel speeds of $\sim 8$ knots (Merchant 2019). The speed limit in Klaipeda Harbour is restricted to exactly 8 knots. However, as seen from Fig. 4, bimodal distributions show accumulation at a lower sound pressure region, as well as at high sound pressure levels, meaning that many ships at Klaipeda Harbour transit at speeds below 8 knots, thereby extending the sound exposure time. This feature implies that the most appropriate noise reduction options at Klaipeda Harbour are the technological ones. By the date of this study, they are described as voluntary options by the International Maritime Organization (IMO) in its ships noise reduction guidelines (IMO 2014).

It is also notable that the International Maritime Organization adopted an initial strategy regarding the reduction of greenhouse gas (GHG) emissions from ships. The target is to reduce the total annual GHG emissions by at least $50 \%$ by 2050 , relative to 2008 values (Leaper 2019). Among ship power sources, electrical propulsion systems (diesel/turbine) are less harmful to the atmosphere and are one of the best alternatives to conventional propulsion (AbdelGawad 2018). Electrical propulsion systems are already widely used to power some ship types. $50 \%$ of passenger-vessels that made calls to the Klaipeda Harbour in 2017 were powered by electric-combined propulsion systems (based on AIS data analysis). As found by Parsons et al. (2020), solar-electric powered passenger ships emit around 10-25 dB lower noise levels compared to vessels with conventional propulsion.

\section{CONCLUSIONS}

Ship source spectral models can be utilized to describe underwater shipping noise emission levels in EU inland waters such as narrow channels, where sound propagation modelling is very complex. The described levels can be reported under the Marine Strategy Framework Directive.

Ship noise emissions acquired throughout 20152017 at Klaipeda Harbour using ships noise emissions modelling indicate that yearly levels dropped in contrast to the increase in loaded cargo tonnage despite increase in global shipping. However, to con- 
firm long-term trends in ship-emitted noise levels, additional observations are required.

The emitted shipping noise might negatively affect sensitive fish species that migrate through the Klaipeda Harbour to their spawning habitats.

Anomalous ship noise levels can be minimized at Klaipeda Harbour by shipping industry, with the technological noise reduction measures being the most appropriate ones, although by the date of this study these measures are listed as voluntary by the International Maritime Organization.

It remains unclear how spectral source levels emitted by merchant ships powered by alternative power sources will deviate from the modelled spectral levels, using available ship-source models for forecasting.

\section{ACKNOWLEDGMENTS}

This research was supported by the RBR (Reviving Baltic Resilience) Interreg-V-A project, grant No. STHB 02.02.00-22-0092/16 of the EU South Baltic Programme 2014-2020. The authors are thankful to the Lithuanian Transport Safety Administration for the automatic ship identification data provided and two anonymous reviewers for their valuable comments that let improve the quality of the manuscript.

\section{REFERENCES}

Abdelgawad, A.F. 2018. A Simple Model of a Ship and Diesel-Electric (DE) Propulsion System. Proceedings of ICFD13: Thirteenth International Conference of Fluid Dynamics 21-22 December, 2018, Cairo, Egypt, 1-11.

Armstrong, C. 2020. Ocean justice: SDG 14 and beyond. Journal of Global Ethic (In press), 1-22. https://doi.or g/10.1080/17449626.2020.1779113

Au, W.W.L., Hastings, C.M. 2008. Principles of marine bioacoustics. Springer Science + Business Media, 2008, 679 pp.

Arveson, P.T., Vendittis, D.J. 2000. Radiated noise characteristics of a modern cargo ship. The Journal of the Acoustical Society of America, 107 (1), 118-129. https://doi.org/10.1121/1.428344

Bagočius, D. 2013. Underwater noise level in Klaipėda Strait, Lithuania. Baltica, 26 (1), 45-50. https://doi:10.5200/baltica.2013.26.05

Balticlines. 2016. Shipping in the Baltic Sea - Past, present and future developments relevant for Maritime Spatial Planning. Project Report I, 35 pp.

Betke, K., Folegot, T., Matuschek, R., Pajala, J., Persson, L., Tegowski, J., Tougaard, J., Wahlberg, M. 2015. BIAS Standards for Signal Processing. Aims, Processes and Recommendations, 2015, 26 pp.

Breeding Jr., J.E., Pflug, L.A., Bradley, M., Walrod, M.H. 1996. Research Ambient Noise Directionality (RANDI) 3.1 Physics Description (No. NRL/FR/7176-95-9628). Naval Research lab Stennis Space Center MS.
Chion, C., Lagrois, D., Dupras, J. 2019. A meta-analysis to understand the variability in reported source levels of noise radiated by ships from opportunistic studies. Frontiers in Marine Science, 6 (714), 1-14. https://doi.org/10.3389/fmars.2019.00714

Crowell, S.C. 2016. Measuring In-Air and Underwater Hearing in Seabirds. In: Popper, A.N., Hawkins, A.D. (eds), Effects of Noise on Aquatic Life II. Springer-Verlag, New York: 1155-1160 pp.

Dekeling, R., Tasker, M., Van Der Graaf, A., Ainslie, M., Andersson, M., André, M., Borsani, J., Brensing, K., Castellote, M., Cronin, D., Dalen, J., Folegot, T., Leaper, R., Pajala, J., Redman, P., Robinson, S., Sigray, P., Sutton, G., Thomsen, F., Werner, S., Wittekind, D., Young, J. 2013. Monitoring guidance for underwater noise in European seas. Part I: executive summary. Part II: monitoring guidance specifications. Part III: background information and annexes. Joint Research Centre Scientific and Policy Reports Eur 6557, 26555, and $26556 \mathrm{En}$. Publications Office of the European Union, Luxembourg (interim reports).

Etter, P.C. 2012. Advanced applications for underwater acoustic modeling. Advances in Acoustics and Vibration, 2012, 1-28. https://doi.org/10.1155/2012/214839

Finfer, D.C., Leighton, T.G., White, P.R. 2008. Issues relating to the use of a $61.5 \mathrm{~dB}$ conversion factor when comparing airborne and underwater anthropogenic noise levels. Applied Acoustics, 69 (5), 464-471. https://doi.org/10.1016/j.apacoust.2007.05.008

Hatch, L., Clark, C., Merrick, R., VanParijs, S., Ponirakis, D., Schwehr, K., Thompson, M., Wiley, D. 2008. Characterizing the relative contributions of large vessels to total ocean noise fields: a case study using the Gerry E. Studds Stellwagen Bank National Marine Sanctuary. Environmental management, 42 (5), 735-752. https://doi.org/10.1007/s00267-008-9169-4

Hildebrand, J.A. 2009. Anthropogenic and natural sources of ambient noise in the ocean. Marine Ecology Progress Series, 395, 5-20. https://doi.org/10.3354/meps08353

ICES. 2020. The International Council for the Exploration of the Sea [Interactive]. https://ices.dk/data/dataportals/Pages/Continuous-Noise.aspx

IMO. 2014. United Nations International Maritime Organization. Guidelines for the reduction of under water noise from commercial shipping to address adverse impacts on marine life. MEPC.1/Circ. 833.

Jalkanen, J.P., Johansson, L., Liefvendahl, M., Bensow, R., Sigray, P., Östberg, M., Karasalo, I., Andersson, M., Peltonen, H., Pajala, J. 2018. Modelling of ships as a source of underwater noise. Ocean Science, 14 (6), 1373-1383. https://doi.org/10.5194/os-14-1373-2018

Jensen, B.F., Kuperman, A.W., Porter, B.M., Schmidt, H. 2011. Computational Ocean acoustics. Second Edition, Springer Science + Business Media, LCC.

Jiang, P., Lin, J., Sun, J., Yi, X., Shan, Y. 2020. Source spectrum model for merchant ship radiated noise in the Yellow Sea of China. Ocean Engineering, 216, 1-13. https://doi.org/10.1016/j.oceaneng.2020.107607 
KSSP. 2020. Klaipeda State Sea Port Authority [Interactive]. Web source https:/www.portofklaipeda.lt/

Liefvendahl, M., Feymark, A., Bensow, R. 2015. Methodology for noise source modelling and its application to Baltic Sea shipping: Deliverable D4. 1 of the BONUS SHEBA project. R/Department of Shipping and Marine Technology, Chalmers University of Technology, (161).

Leaper, R.C. 2019. The role of slower vessel speeds in reducing greenhouse gas emissions, underwater noise and collision risk to whales. Frontiers in Marine Science, 6, 505, 1-8. https://doi.org/10.3389/fmars.2019.00505

Madsen, P.T., Wahlberg, M., Tougaard, J., Lucke, K., Tyack, P. 2006. Wind turbine underwater noise and marine mammals: implications of current knowledge and data needs. Marine Ecology Progress Series, 309, 279-295. https://doi:10.3354/meps309279

Maksimov, J., Toliušis, ک̌S., Balčiūnas, J. 2007. Twaite Shad reproductors and juveniles' abundance and distribution in Baltic Sea Lithuanian economic zone. Fishery in Lithuania, (VII), 89-99.

Merchant, N.D. 2019. Underwater noise abatement: economic factors and policy options. Environmental Science \& Policy, 92, 116-123. https://doi.org/10.1016/j.envsci.2018.11.014

MMC. 2007. Marine mammals and noise. A Report to Congress from the Marine Mammal Commission.

Mustonen, M., Klauson, A., Andersson, M., Clorennec, D., Folegot, T., Koza, R., Pajala, J., Persson, L., Tegowski, J., Tougaard, J., Wahlberg, M., Sigray, P. 2019. Spatial and temporal variability of ambient underwater sound in the Baltic Sea. Scientific reports, 9 (1), 1-13. https://doi.org/10.1038/s41598-019-48891-X

Parsons, M.J., Duncan, A.J., Parsons, S.K., Erbe, C. 2020. Reducing vessel noise: An example of a solar-electric passenger ferry. The Journal of the Acoustical Society of America, 147 (5), 3575-3583. https://doi.org/10.1121/10.0001264
Popper, A.N., Hawkins, A.D., Fay, R.R., Mann, D.A., Bartol, S., Carlson, T.J., Coombs, S. Ellison, W.T., Gentry, R.L., Halvorsen, M.B., Løkkeborg, S., Rogers, P.H., Southall, B.L., Zeddies, D.G., Tavolga, W.N. 2014. Sound Exposure Guidelines for Fishes and Sea Turtles: A Technical Report prepared by ANSI-Accredited Standards Committee S3/SC1 and registered with ANSI.

Ross, D. 1987. Mechanics of underwater noise. Peninsula publishing, CA, Los Al-tos, 389 pp.

Slabbekoorn, H., Bouton, N., VanOpzeeland, I., Coers, A., Ten Cate, C., Popper, A.N. 2010. A noisy spring: the impact of globally rising underwater sound levels on fish. Trends in ecology \& evolution, 25 (7), 419-427. https://doi.org/10.1016/j.tree.2010.04.005

Tasker, M.L, Amundin, M., Andre, M., Hawkins, A., Lang, W., Merck, T., Scholik-Schlomer, A., Teilmann, J., Thomsen, F., Werner, S., Zakzaria, M., Zampoukas, N. 2010. MARINE STRATEGY FRAMEWORK DIRECTIVE. Task Group 11 Report. Underwater noise and other forms of energy. Publications Office of the European Union, 64 pp.

Trimonis, E., Gulbinskas, S., Kuzavinis, M. 2003. The Curonian Lagoon bottom sediments in the Lithuanian water area. Baltica, 16, 13-20.

Urick, R.J. 1979. Sound propagation in the sea. Washington D.C 20046. The Catholic University of America, 242 pp.

Urick, R.J. 1983. Principles of underwater sound. 3rd edition. Peninsula publishing.

Urick, R. J. 1984. Ambient noise in the sea. Technical Report, Undersea Warfare Technology Office, Naval Sea Systems Command, Department of the Navy, Washington, DC, 194 pp.

Wittekind, D.K. 2014. A simple model for the underwater noise source level of ships. Journal of Ship production and design, 30 (1), 7-14. http://dx.doi.org/10.5957/JSPD.30.1.120052 